\title{
Effect of Training and Development on Employee Satisfaction: A Case of the Judiciary of Kenya
}

\author{
Joseph Ouma Osewe and Jarso Yussuf Gindicha
}

\begin{abstract}
Abstract -The study aimed determining the relationship between training and development and employee job satisfaction in the Judiciary of Kenya. The research used explanatory cross-sectional survey design. The research population consisted of 5,419 judicial officers and staff. Structured questionnaires containing closed-ended questions were sent to all employees via their e-mails. 2,684 employees representing $50 \%$ of the population returned filled questionnaires. Statistically this was large enough to render the results permissible and acceptable as a representation of the entire population. This method was preferred because of the large number of subjects, cost, time, and the nature of the topic. The results indicated that training and development has positive correlation with employee satisfaction. Further, training need, training relevance, training work related, and number of trainings are positively correlated to employee satisfaction by $0.705,0.835,0.817$ and 0.514 respectively. The study shows that training and development could contribute to increase in employee satisfaction.
\end{abstract}

Key words - Employee satisfaction; Training; Development.

\section{INTRODUCTION}

\section{A. Background of the Study}

Human capital is recognized as one of the intangible assets of business organizations where the skills, talents, and knowledge that employees possess are strongly linked to the organizations' strategies and performances [3]. Consistently, there is a well-proven evidence suggesting that, as one of the many complex human resource practices, employee training, can significantly influence the success of an organization through different channels like learning, innovation, employee motivation, skill upgrading, etc. [20].

Behaviors are modified systematic and planned by training methods through learning events, programmers, and instructors, which will help employees perform their jobs effectively because training allows individuals to gain a level of knowledge, skills, and competencies [2]. Access to training, according to is an opportunity to participate in training. [12] argued that Access to training is the extent to which employees are able to get training opportunities. In essence, improving productivity, superior products, and services quality, and maximizing or optimizing resources are the tangible outcomes of training and development.

Job satisfaction on the other hand is viewed as a positive emotional state resulting from the pleasure a worker derives

Published on June 25, 2021

Dr. Joseph Ouma Osewe, PhD, Assistant Director, Planning \& Organizational Performance, Judiciary, Kenya.

(corresponding e-mail: josephosewe74@ gmail.com) from the job, a state where one's needs and one's outcomes match well and conceptualized in terms of satisfaction with work, involvement in work and commitment to work. Employees are expected to be happy with their work; this makes job satisfaction an issue of substantial importance for both employer and employees. Unfortunately, many organizations have failed to include job satisfaction on their priority lists [16]. How much employees are satisfied with their job is an important pointer in employee satisfaction [12]. There are several benefits associated with training including consistency in job performance, greater job satisfaction, higher customer satisfaction, and reduction in business costs. [9] established that training is one of the vital human resource management practices that positively affect the quality of the workers knowledge and skills, and this results in higher employee performance on job.

Unfortunately, companies do not tend to put forth much effort into implementing effective training techniques and programs. Management lack of willingness to invest in training programs, has resulted into a cycle where poor training of employees and the consequential lack of motivation and poor commitment of employees is neverending [11]. At the present time, the rich labor market has created favorable conditions and other opportunities for employees to choose if they feel dissatisfied or unhappy in their position. Recently, they are willing to be able to transfer to other organizations [15]. Therefore, rapid training will help organizations to solve these situations.

\section{B. Statement of Problem}

The Judiciary of Kenya spends a huge budget in training and development of employees. These budgets are over Kenya shillings 140 million every year for Judicial Officers and staff. These amounts are allocated to training and development hoping that skills and expertise will improve enabling them to improve their performance and undertake greater work responsibilities. Ideally, the huge spending should result in higher productivity and performance and enhance employee satisfaction.

Results of survey reveal the contrary and it seems the lack of motivation and poor commitment of employees is a neverending problem. Employee satisfaction and work environment survey conducted in 2019 indicate a drop in the satisfaction index of employees from 64 to 60 in 2017 and 2019 respectively. The training budget therefore remains a routine. It is against this backdrop that this research sought to

Jarso Yussuf Gindicha, Program Officer, Planning \& Organizational Performance, Judiciary, Kenya.

(e-mail: yusufjarso.yj @ gmail.com). 
find out the effect of training and development on employee satisfaction in the Judiciary of Kenya.

\section{Research Objective}

The general objective of this study is to investigate the effect of training and development on employee satisfaction in the Judiciary of Kenya

Specific objectives of the study include:

i. Assess the effect of training needs assessment on employee satisfaction;

ii. Assess the effect of relevance of training and employee satisfaction;

iii. Assess the effect of number of trainings offered and satisfaction of employees;

iv. Assess the effect of training support and satisfaction of employees;

v. Assess the effect of training significance and satisfaction of employees.

\section{LITERATURE REVIEW}

\section{A. Theoretical Review}

\section{1) Human Capital Theory}

This study is anchored on Human capital theory. Human capital theories have developed rapidly since Mincer (1958, 1962), Schultz (1960, 1961), Becker (1962) and Ben-Porath (1967). Human capital theory is based on neo-classical theories of labor markets, education, and economic growth. It takes for granted that employees are productive resources and attempts to find out whether highly trained staff are more productive than other personnel [17]. As employees do not obtain considerable pay increases due to increased productivity after attending specific training sessions, they will not be motivated to finance their own training requirements. On the other hand, companies will be keen to cover these training costs, as they will obtain almost all the returns from the enhanced productivity produced by the new skills generated [16]. The trainings considered in this study are vocational, on-the-job, or professional training which were fully financed by the Judiciary hence in return expects trained employees to improve job satisfaction and in return their satisfaction.

\section{2) Training and Development and Employee Satisfaction}

In the increasingly globalizing working environments, it is required that business organizations acquire well-educated and trained employees who are capable to adapt themselves rapidly to their ever-changing workplaces where new necessities for businesses have arisen. Therefore, organizations investing in training programs are able to gain a competitive advantage compared to their counterparts with no training services [3]. Employee training is associated with on-the-job skills needed for a particular role. Training can be distinguished between general and organizational training. General training embodies explicit knowledge and skills that can be easily learned and obtained by reading or observing with no intended help of others. Organizational training, on the other hand, is about tacit knowledge and skills acquired through intra-organization intended efforts. Training is widely recognized and labeled as vocational, on-the-job, or professional training.

The crucial necessity of training comes from today's increasing competitiveness of business environment in which technological progress, productivity measurements, product differentiations, customer expectations, intra- and interindustry relations, employee motivations, etc. have been changing dramatically. Under this murky working climate, the only certainty is that there are more change pressures than ever before, and they affect all of the organizations. In this process, more efficient business organizations are those adapting their employees to these changes. The main instrument for this is training the employees to keep them updated with and ready to the changes that can be attributed to the diversity training which facilitate positive inter-group interactions and enhance the skills, knowledge and motivation of employees [8].

The direct gains of business organizations from training might be summarized as job proficiency, job performance and personal motivation based on time, energy, and moneysaving benefits. Therefore, training is usually found stimulating productivity in organizations Employee satisfaction [3]. The only sustainable advantage an organization will have in the future is its ability to learn faster than its competitors. This competitive advantage can be achieved by transforming the organization into a learning organization. For this reason, today it is seen imperative that organizations need to update and upgrade their employees' talents and skills by teaching and training the workforce for long-term sustainable competitiveness [19]. This will successively make employees satisfied with their jobs and satisfied employees consequently increase the overall productivity of businesses which is one of the main strategies of them [3]

We therefore present the hypothesis:

$H_{1}$ : There is a significant relationship between training and development and employee satisfaction.

\section{3) Training Needs Assessment and Employee Satisfaction}

Training need is defined as shortage of skills or abilities, which can be reduced or eliminated through education and development. Training requirements hinder employees in the fulfillment of their job responsibilities or prevent an organization from achieving its objectives [13]. Prior to organizing any training programs training needs analysis (TNA) is vital to identify workers that need training. TNA tells about what type of training is needed, where training should be carried out, how it should be conducted and managed, when training is significant etc. Training will be successful if given to the right workers (workers who need training) and therefore necessitate the skills to identify the right workers.

TNA is basically a method of finding a suitable employee for the training. It confirms training participation of those workers that have deficiencies in the level of current skills. Workers deficient in skills always exhibit poor performance [13]. TNA describes the variance in the current and needed skills and therefore assist in the evaluation of workers' performance and their contributions towards the attainment of organizational goals. Another important benefit of TNA is that it is cost effective, avoids skill reiteration, and impedes inclusion of trivial training contents in the training module. Moreover, TNA is significant and mandatory if an organization faces financial constraints. According to 
Vasudevan, (18), training commitment, training needs assessment, training contents, delivery approaches and training evaluation positively and significantly influence the employee's work commitment, job satisfaction, and job performance.

We therefore present the hypothesis:

$\mathrm{H}_{2}$ : There is a significant relationship between training needs assessment and employee satisfaction.

\section{4) Relevance of Training and Employee Satisfaction}

In order to ensure a training program is effective, the training has to meet the needs and expectations of the employees. An effective training program indicates that the management provides its employees with precise and truthful information and communicates the objectives of the training to ensure that such trainings are relevant to their careers [10]. A precursor to ensuring the training is relevant is conducting of training needs assessment. TNA is cost effective, avoids skill reiteration, and impedes inclusion of trivial training contents in the training module.

For the training to be relevant it should address overall management needs, and aim to improve service levels and morale, these requirements are derived from the analysis of the objectives and priorities of the organization and are affected by economic and social realities and the prevailing political and technological environment. At job level, they represent weaknesses and deficiencies in the job due to lack of skills and information and directions required to perform various functions and identify the problems and difficulties of functionality which can be treated with structured training [13].

At individual level, the trainings should address the requirements which stem from the work of an individual, recognizable by identifying deficiencies in information and skills and individual and trends that can be developed so that individual can perform his functions well. At group level, the trainings should relate to specific functional levels or certain categories of workers such as managers, supervisors, and implementing direct, and so on. And by analyzing the needs of the community may show the need for a certain type of training programs aimed at the composition of the team spirit and leadership training, supervision and problem solving.

We therefore present the hypothesis:

$\mathrm{H}_{3}$ : There is a significant relationship between relevance of training and employee satisfaction.

\section{5) Number of trainings offered and employee Satisfaction}

According [4], reciprocity in training essentially states that an employee will help the company because the company helped them. This parallels the notion of the employee having a sense of debt toward the organization. Training can play an integral role in building a sense of debt to an organization. Training that achieves reciprocity in the employee will foster an individual's commitment to the organization. Organizations that train their employees consistently have better outcomes than those that do not. It is believed that when business environments change quickly and abruptly, it is typically the companies with the best trained employees that adapt and adjust most efficiently.

Employees that participated in the most number of training programs and rated the trainings they attended as most relevant, viewed the organization as being more supportive, looked at the company more favorably, and had less of an intent to quit [5] One could argue that training was able to enhance the employee's sense of debt towards the organization. The result is a more committed employee that has a greater desire to remain. If the organization invests in more trainings on an employee, he will feel indebted to the organization and is bound to reciprocate by remaining committed and by extension satisfied

We therefore present the hypothesis:

$\mathrm{H}_{4}$ : There is a significant relationship between number of trainings offered and employee satisfaction.

\section{6) Training Support and Employee Satisfaction}

Investing in the training and development of employees is an effective method to develop a competitive human resource pool. Among the input factors incurred by an organization, financial investment is the most straightforward indicator of organizational commitment and resource expenditure related to training. Intensive and well-organized corporate trainings are resource dependent and must be supported by appropriate resource input, such as a sufficient budget. the monetary investment of firms in training has been highlighted as the most basic requirement to ensure both opportunities and quality of training for employees [20].

Corporate training expenditure is the investment for firmspecific, internal training that aims to achieve immediate skill building and performance gain, which directly address the current and impending training needs of an organization. Organizations allocate budgets to initiate training programs that are mostly developed and delivered in-house to provide organization-specific and task-relevant instructions, thus reinforcing firm-specific human capital needs in a short term. This method is designed and delivered to employees in various formats like lectures, workshops, site visits, and case analyses and media [20]. Corporate training therefore promotes fast and effective learning and adaptation to new tasks and situations encountered by employees, thereby increasing employees' openness to innovative ideas and their ability to make constructive proposals for changes that may not be gained from their daily routine. Given that intensive and well-organized corporate trainings are resource dependent and must be supported by appropriate investment [20]. Financial investment in training is critical in ensuring both opportunities and quality training for employees.

We therefore present the hypothesis:

$H_{5}$ : There is a significant relationship training support and employee satisfaction.

\section{B. Conceptual Framework}

In this study, the Fig. 1 depicts the relationship between training and development and employee satisfaction in the Judiciary of Kenya.

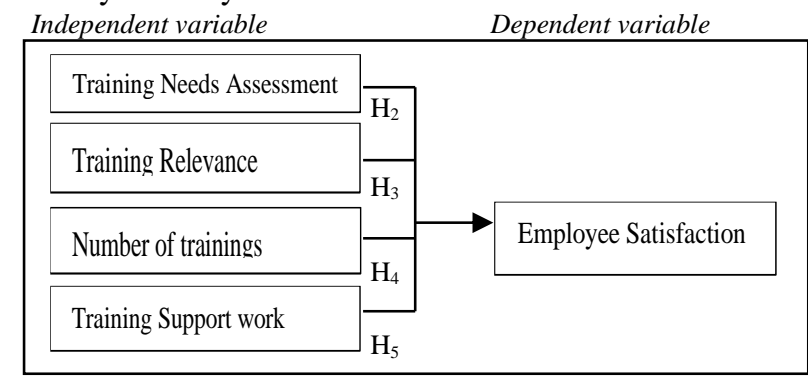

Fig. 1. Conceptual framework. 


\section{RESEARCH METHODOLOGY}

\section{A. Research Design and Approach}

The research design used for this study was explanatory cross sectional survey design, since the study only intended to pick some representative sample elements of the of the population and it was conducted across participants over a short period of time.

Quantitative approach was used in this study; employees were selected by a simple random sampling method. Structured questionnaires containing closed questions were sent to staff. The questionnaires were preferred because of the large number of subjects, cost, time, and the nature of the topic.

\section{B. Study Population, Sampling Design and Sample Size}

Population as the total collection of elements about which one wants to make inferences [6]. The study population comprised of Judicial Officers (judges, magistrates and Kadhis) and judicial staff.

Simple random sampling was used. A total of 2,684 employees out of a possible 5,419 Judicial Officers and staff returned the filled questionnaires. This represents $50 \%$ of the population. Statistically this was large enough to render the results permissible and acceptable as a representation of the entire Judiciary Officers and staff population.

\section{Data Collection}

This study used questionnaires as an instrument for collecting data. The questionnaires were sent through the staff emails and in areas where there was non-response a followup was done, and questionnaires issued for selfadministration.

\section{Validity and Reliability Tests}

Validity was tested using the variance inflation factor (VIF). The results indicate a $\mathrm{VIF}<5$ indicating that there were no multi-collinearity problems concerning the estimations of training and development dimensions. These tests indicate that all variables met the threshold for multi-collinearity and were thus all used for further analysis using multiple linear regression as shown in Table I.

Cronbach's alpha $(\alpha)$ was used to estimate internal consistency by determining how all items on a test relate to all other items and to the total test. The reliability is expressed as a coefficient between 0 and 1.00. The higher the coefficient, the more reliable is the test. The recommended value of 0.7 was used as a cut-off of reliabilities. The findings are indicated in Table II.

TABLE I: VALIDITY AND RELIABILITY TEST RESULTS

\begin{tabular}{ccc}
\hline \hline Variable & VIF & Cronbach's alpha $(\alpha)$ \\
\hline Training Needs Assessment & 1.98 & 0.7388 \\
Training Relevance & 1.83 & 0.7714 \\
Number of Trainings & 1.41 & 0.8221 \\
Training Support employees work & 2.12 & 0.7382 \\
\hline \hline
\end{tabular}

\section{RESULTS}

\section{A. Demographic Information}

On gender, $52.4 \%$ of the respondents were male while $47.6 \%$ females. A total of $37.6 \%$ of the employees were aged between 33 and 42 years, $34 \%$ were aged between 23 and 32 years, while $15.8 \%$ were aged between 43 and 52 years. The respondents who were aged 53 years and above were $9.7 \%$ while those below 22 years were $2.8 \%$. On education, The Survey results indicate that $28.9 \%$ of the employees were Diploma holders, followed by those with O-level qualifications at 25.6 per cent, graduates at $24.8 \%$, and postgraduates at 11 per cent and higher diploma at 6 per cent as shown in Table III.

TABLE II: DEMOGRAPHIC INFORMATION

\begin{tabular}{|c|c|c|c|}
\hline Variable & & Frequency & Percentage \\
\hline \multirow[t]{2}{*}{ Gender } & Male & 1,246 & $52.4 \%$ \\
\hline & Female & 1,134 & $47.6 \%$ \\
\hline \multirow[t]{5}{*}{ Age } & Below 22 yrs & 75 & $2.8 \%$ \\
\hline & $23-32$ yrs & 904 & $34.0 \%$ \\
\hline & $33-42 y r s$ & 1000 & $37.6 \%$ \\
\hline & 43-52 yrs & 421 & $15.8 \%$ \\
\hline & Above 53 yrs & 259 & \\
\hline \multirow[t]{7}{*}{ Years in Service } & less $1 \mathrm{yr}$ & 36 & $1.4 \%$ \\
\hline & $1-5 \mathrm{yrs}$ & 875 & $33.2 \%$ \\
\hline & $6-10$ yrs & 638 & $24.2 \%$ \\
\hline & $11-14$ yrs & 257 & $9.8 \%$ \\
\hline & $15-19 y r s$ & 412 & $15.6 \%$ \\
\hline & $20-24$ yrs & 152 & $5.8 \%$ \\
\hline & over $25 y$ rs & 263 & $10.0 \%$ \\
\hline \multirow[t]{7}{*}{ Education level } & Primary Level & 35 & $1.3 \%$ \\
\hline & A - Level & 63 & $2.4 \%$ \\
\hline & $\mathrm{O}$ - Level & 683 & $25.6 \%$ \\
\hline & Diploma & 679 & 28.9 \\
\hline & Higher Diploma & 151 & $5.7 \%$ \\
\hline & Graduate & 661 & $24.8 \%$ \\
\hline & Postgraduate & 302 & $11.3 \%$ \\
\hline Valid $\mathrm{N}=2,450$ & & & \\
\hline
\end{tabular}

\section{A. Descriptive Statistics}

Descriptive analysis was conducted for statements on training and development and employee satisfaction as shown in Table III.

TABLE III: DESCRIPTIVE ANALYSIS

\begin{tabular}{ccc}
\hline \hline Variable & Mean & Std. Deviation \\
\hline Training Needs Assessment & 2.137 & 0.880 \\
Training Relevance & 2.637 & 0.885 \\
Number of Trainings & 1.714 & 0.824 \\
Training Support employees work & 2.500 & 0.891 \\
\hline \hline
\end{tabular}

The results in Table III show that low standard deviation and means was scored on all the factors, and this indicates a low variation. This means that the questions were well answered, and answers given were accurate and reliable.

\section{B. Correlation Analysis}

Correlation analysis was conducted to check the relationship between independent variables and dependent variable. The results are indicated in Table IV.

$H_{l}$ : sought to establish whether training and development and employee satisfaction are positively related. The results established that there is a positive relationship between training and employee satisfaction $\left(\mathrm{r}=.293^{* *}, \mathrm{p}<0.001\right)$; thus, $\mathrm{H} 1$ was accepted.

$\mathrm{H}_{2}$ : sought to establish whether training needs assessment and employee satisfaction are positively related. The results established that there is a positive relationship between training need and employee satisfaction $\left(\mathrm{r}=0.303^{* *}, \mathrm{p}<\right.$ $0.001)$; thus, H2: was accepted. 
$H_{2}$ : sought to establish whether relevance of training and employee satisfaction are positively related. The results established that there is a positive relationship between training need and employee satisfaction $(\mathrm{r}=0.251 * *, \mathrm{p}<$ 0.001 ); thus, H3 was accepted.

$H_{4}$ : sought to establish whether number of training an employee gets and employee satisfaction are positively related. The results established that there is a positive relationship between training need and employee satisfaction $\left(\mathrm{r}=0.229^{*} * \mathrm{p}<0.001\right)$; thus, $\mathrm{H} 4$ was accepted.

$\mathrm{H}_{5}$ : sought to establish whether if training offered supports the work of employees and employee satisfaction are positively related. The results established that there is a positive relationship between training need and employee satisfaction $\left(r=0.293^{* *}, \mathrm{p}<0.001\right)$; thus, H5 was accepted.

\section{TABLE IV: CORRELATION ANALYSIS}

\begin{tabular}{|c|c|c|c|c|c|}
\hline Variable & SI & TNA & TR & NT & TSW \\
\hline SI & 1.000 & & & & \\
\hline TNA & $\begin{array}{c}0.303 * * \\
0.000\end{array}$ & 1.000 & & & \\
\hline TR & $\begin{array}{c}0.251 * * \\
0.000\end{array}$ & $\begin{array}{c}0.550 * * \\
0.000\end{array}$ & & & \\
\hline NT & $\begin{array}{c}0.229 * * \\
0.000\end{array}$ & $\begin{array}{c}0.527 * * \\
0.000\end{array}$ & $\begin{array}{c}0.371 * * \\
0.000\end{array}$ & & \\
\hline TSW & $\begin{array}{c}0.293 * * \\
0.000\end{array}$ & $\begin{array}{l}.622 * * \\
0.000\end{array}$ & $\begin{array}{c}0.646 * * \\
0.000\end{array}$ & $\begin{array}{c}0.431 * * \\
0.000\end{array}$ & 1.000 \\
\hline
\end{tabular}

**. Correlation is significant at the 0.01 level (2-tailed).

Key: SI - Satisfaction Index; TNA - Training Need Assessment; TR Training Relevance; NT - Number of training; TSW - Training Support work.

\section{Multiple Regression Results}

The results in Table $\mathrm{V}$ show that training and development was satisfactory in explaining employee satisfaction. This is supported by coefficient of determination of 0.113 . This means that training and development is a good predictor of employee satisfaction by $11.3 \%$

TABLE V: MODEL SUMMARY

\begin{tabular}{cccccc}
\hline \hline Model & $\mathrm{R}$ & $\mathrm{R}^{2}$ & $\begin{array}{c}\text { Adjusted } \\
\mathrm{R} 2\end{array}$ & $\begin{array}{c}\text { Std. error of } \\
\text { the Estimate }\end{array}$ & $\begin{array}{c}\text { Durbin- } \\
\text { Watson }\end{array}$ \\
\hline 1 & $0.336 \mathrm{a}$ & 0.113 & 0.111 & 8.146 & 0.476 \\
\hline \hline
\end{tabular}

a. Predictors: (Constant), number of trainings sufficient, training relevance, training need, training support work one does.

b. Dependent Variable: Satisfaction Index.

\section{ANOVA Results}

The results in Table VI indicate that the overall model was statistically significant. This was supported by an F statistic of 79.249 and the reported $\mathrm{p}$ value $(\mathrm{p}<0.001)$. The results imply that employee training and development is a good predictor of employee satisfaction.

TABLE VI: ANOVA RESULTS

\begin{tabular}{ccccccc}
\hline \hline \multirow{2}{*}{ Model } & $\begin{array}{c}\text { Sum of } \\
\text { Squares }\end{array}$ & df & $\begin{array}{c}\text { Mean } \\
\text { Square }\end{array}$ & f & Sig. \\
& Regression & 21035.12 & 4 & 5258.78 & 79.25 & $<0.001$ \\
1 & Residual & 165561.47 & 2495 & 66.357 & & \\
& Total & 186596.6 & 2499 & & & \\
\hline \hline
\end{tabular}

a. Dependent Variable: Satisfaction index.

b. Predictors: (Constant), number of trainings sufficient, training relevance, training need, training support work.

\section{E. Coefficients}

The $\mathrm{t}$ test was done on the relationship between the independent and the dependent variables and the results are shown in Table VII.

TABLE VII: COEFFICIENTS

\begin{tabular}{|c|c|c|c|c|c|}
\hline \multirow{2}{*}{ Model } & \multicolumn{2}{|c|}{$\begin{array}{l}\text { Unstandardized } \\
\text { Coefficients }\end{array}$} & \multirow{2}{*}{$\begin{array}{c}\text { Standardized } \\
\text { Coefficients } \\
\text { Beta }\end{array}$} & \multirow{2}{*}{$\mathrm{t}$} & \multirow{2}{*}{ Sig. } \\
\hline & B & $\begin{array}{l}\text { Std. } \\
\text { Error }\end{array}$ & & & \\
\hline (Constant) & 32.394 & 0.562 & & & \\
\hline TNA & 1.471 & 0.260 & 0.150 & 57.64 & 0.000 \\
\hline TR & 0.577 & 0.249 & 0.059 & 5.650 & 0.000 \\
\hline TSW & 1.278 & 0.267 & 0.131 & 2.319 & 0.020 \\
\hline NT & 0.689 & 0.235 & 0.066 & 4.780 & 0.000 \\
\hline
\end{tabular}

Regression of coefficients showed that training need analysis and employee satisfaction had a positive and significant relationship $(\mathrm{B}=1.471, \mathrm{p}<0.001)$. The results also revealed that training relevance and employee satisfaction had a positive and significant relationship $(B=0.577$, $\mathrm{p}<0.025)$. The results also revealed that trainings support the work of employees and employee satisfaction had a positive and significant relationship $(\mathrm{B}=1.278, \mathrm{p}=<0.001)$. Further the results revealed that the number of trainings an employee receives, and employee satisfaction had a positive and significant relationship $(\mathrm{B}=0.689, \mathrm{p}=<0.025)$.

This means that Judiciary should put a lot of emphasis on training. From the $\mathrm{t}$ test, the regression coefficients of the variables are presented according to the effect on the overall model as:

$$
\begin{aligned}
E S=1.471 \mathrm{TNA} & +0.577 T R+0.689 N T+1.278 \mathrm{TSW} \\
+ & 32.394
\end{aligned}
$$

where

ES- Employee satisfaction;

TNA- Training Needs Assessment;

TR- Training Relevance;

NT-Number of trainings;

TSW- Training supports employee work.

\section{F. Discussion}

Organizations must answer the question on how they will sustain their ability to change and improve. This indicates the commitment of the organization growth and adaptation and measures the organization's ability to do innovation, improve its employee and product or services. For employees to increase their ability to adapt effectively with the rapid changes in the Judiciary, training, and development must be one of the strategies since through it, employee satisfaction is enhanced. Learning the soft, technical skills required by the job are the benefits that employees receive after the training program ends. Therefore, employees can survive and develop their ability to cope with new technologies in the future. To be more specific, employees who are satisfied with the training content tend to stick with the business more because they feel pleased with the knowledge and professional skills provided by the company.

\section{G. Theoretical Implications and Areas of Further Research}

The findings offer an alternative theoretical position for exploring employee satisfaction from the perspective of 
training and development. The findings confirm that training and development, is a key antecedent of employee satisfaction. It also enriches the human capital theory that employees are not motivated to finance their own trainings, hence it is the responsibility of the organizations to boost their productivity by sponsoring their trainings, since such trainings are positively correlated to employee satisfaction. Hence, the results of this study provide strong empirical support for our hypotheses that training, and development is positively correlated to employee satisfaction. Training plays an integral role in building a sense of debt to an organization. Training that achieves reciprocity in the employee will foster an individual's commitment to the organization enhancing job satisfaction and employee satisfaction. Further research can focus on establishing the relationship between employee satisfaction and employee retention because most organizations would want to reduce employee turnover because there may be satisfied employees who still leave the organization.

\section{H. Managerial Implications}

Managers should consider training and development as a very important component of employee satisfaction. In the Kenyan Judiciary, training needs to be properly coordinated and budgeted for to enhance employee performance. Such budgets should take into account training needs analysis where employees are involved and communication is open, relevance of the trainings offered, the number of trainings and consider whether the trainings support the work of employees. Management is therefore informed to reliably utilize this result to make favorable decisions regarding training and development, since it has a direct impact on employee satisfaction. Training and development act as an antecedent for employee satisfaction in the Judiciary.

\section{Conclusion}

The findings of this study have outstanding managerial, policy, and theoretical implications. The results place a demand for managers to act. This study finds that training and development, and in particular training needs analysis, training relevance, number of trainings offered to employees and whether the training is work related to be very important in Judiciary in predicting employee satisfaction. For policymakers, they should realize employee satisfaction does not come by chance; effort must be made to have it. Therefore, policies regarding training and development, should be made without hesitation and implemented. [7] attests that organizations that provide training to employees do promote employee dedication to their work, so will increase employee satisfaction and performance.

\section{REFERENCES}

[1] Anwar, Govand, and Inji Shukur. "The Impact of Training and Development on Job Satisfaction: A Case Study of Private Banks in Erbil." International Journal of Social Sciences \& Educational Studies 2.1 (2015): 65.

[2] Armstrong, Jim. "Improving international capacity development." Bright Spots. Palgrave Macmillan, 2013.

[3] Asgarova, Aygul. "Impact of Employee Training on Employee Job Satisfaction and Achievement: A Case of Turkish Manufacturing Industry." Available at SSRN 3398117 (2019).

[4] Brum, Scott. "What impact does training have on employee commitment and Employee turnover?" (2007).
[5] Burke, Ronald J. "Benefits of formal training courses within a professional services firm." Journal of Management Development (1995).

[6] Cohen, Louis, Lawrence Manion, and Keith Morrison. Research methods in education. routledge, 2002.

[7] Dardar, Abdul Hakim Ahmad, Ahmad Jusoh, and Amran Rasli. "The impact of job training, job satisfaction and alternative job opportunities on job turnover in Libyan oil companies." Procedia-Social and Behavioral Sciences 40 (2012): 389-394.

[8] DEMIRAL, Özge. "Effects of training on employee job satisfaction and achievement: 'train to gain'evidence from manufacturing businesses in turkey." Business \& Management Studies: An International Journal 5.3 (2017): 765-785.

[9] Elnaga, Amir, and Amen Imran. "The effect of training on employee performance." European journal of Business and Management 5.4 (2013): 137-147.

[10] Hanaysha, Jalal. "Examining the effects of employee empowerment, teamwork, and employee training on organizational commitment." Procedia-Social and Behavioral Sciences 229 (2016) 298-306.

[11] Jaworski, Caitlin D., Swathi Ravichandran, A. Karpinski and Shweta Singh. "The effects of training satisfaction, employee benefits, and incentives on part-time employees' commitment.

[12] Khan, Asad, Hamida Begum, and Fauz Dar Khan. "High-Tech Functional and Professional Skills, Generic Job Satisfaction, and Training Needs of the Pakistani University Librarians: An Empirical Appraisal."

[13] Man, Norsida Binti, et al. "Training needs of agricultural extension agents using Borich Needs Assessment Model." Asian Journal of Agricultural Extension, Economics \& Sociology (2016): 1-19.

[14] Newman, Alexander, Rani Thanacoody, and Wendy Hui. "The impact of employee perceptions of training on organizational commitment and turnover intentions: a study of multinationals in the Chinese service sector." The international journal of human resource management 22.8 (2011): 1765-1787.

[15] Nguyen, C., \& Duong, A. The Impact of Training and Development, Job Satisfaction and Job Performance on Young Employee Retention. International Journal of Future Generation Communication and Networking, vol. 13, No. 3, 2020, pp. 373 - 386.

[16] Picho, Epiphany Odubuker. The Relationship between employee training and development and job satisfaction in Uganda Management Institute: an empirical study. Global Journal of Commerce \& Management Perspective, vol.3 (4):182-188 (July-August, 2014).

[17] Quiggin, John. "Human capital theory and education policy in Australia." Australian Economic Review 32.2 (1999): 130-144.

[18] Saleh, Jasim Mohammed, et al. "Training needs of agriculture extension officers in Iraq." International Journal of Scientific and Research Publications 6.2 (2016): 147-152.

[19] Schroeder, Harold. "The importance of human resource management in strategic sustainability: An art and science perspective." Journal of Environmental Sustainability 2.2 (2012): 4.

[20] Sung, S. Y., \& Choi, J. N. (2014). Do organizations spend wisely on employees? Effects of training and development investments on learning and innovation in organizations. Journal of organizational behavior, 35(3), 393-412. https://doi.org/10.1002/job.1897.

[21] Wang, Yuping, Nian-Shing Chen, and Mike Levy. "The design and implementation of a holistic training model for language teacher education in a cyber face-to-face learning environment." Computers \& Education 55.2 (2010): 777-788

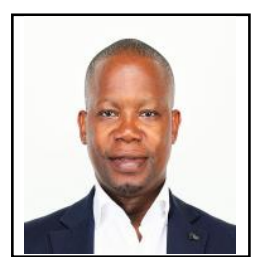

Dr. Joseph Ouma Osewe was born in Kenya on $29^{\text {th }}$ December 1974. He obtained a Ph.D. in Business Administration from Jomo Kenyatta University of Agriculture and Technology in Kenya in 2019. He also obtained an MBA from Kenyatta University in 2003 and a B.Tech (Hons) degree from Moi University in 1998 focal area being Industrial Engineering both institutions are located in Kenya. He was the Head of Productivity Improvement and Quality Assurance and later on Deputy Director in charge of Strategy and Change at Kenya Wildlife Service between 2008 and 2013. He is currently an Assistant Director, Planning and Organizational Performance at the Judiciary of Kenya. His interests include Organizational Strategy, Performance Management, Quality Assurance and Innovation, Planning and Research. 


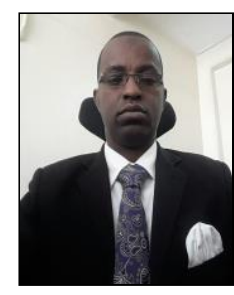

Jarso Yussuf Gindicha was born in Kenya on $6^{\text {th }}$ May, 1978. .He has Bsc Actuaral Science (with IT) from Maseno University, 2021. He has Diploma in Actuarial Science from Technical University of Kenya, 2013. He is a Program Officer, Planning and Organizational Performance, Judiciary Kenya, His areas of interest are research, data analysis and performance management.

He has been involved in Judiciary publication such as the State of the Judiciary Report, Court user and employee survey report, Performance Measurement and Understanding reports and Strategic Plan 2019_2023. 